\title{
Analysis of present evaluation system of the applied undergraduate innovation and entrepreneurship education
}

\author{
Wei wang ${ }^{1, ~ a}$, Na Wang ${ }^{1, b, ~ * ~}$ \\ ${ }^{1}$ Shenyang Institute of Technology, Shenyang 113122, China \\ ${ }^{2}$ School of Management, Changchun Science and Technology University, Changchun 130600, China \\ a380156193@qq.com, b40191584@qq.com \\ *corresponding author
}

Keywords: Applied undergraduate, innovation and entrepreneurship education, evaluation system

\begin{abstract}
College innovation and entrepreneurship education is to train students to possess the pioneering consciousness, spirit and ability. Innovation and entrepreneurship education is an important measure to promote the reform and development of higher education. The establishment of a scientific evaluation system of innovation and entrepreneurship education is a guarantee of the quality. Currently the establishment mode of applied undergraduate evaluation system of innovation and entrepreneurship education is mainly constructed by college and social. The evaluation index is not enough in-depth to meet the complexity of the evaluation system of innovation and entrepreneurship education. Objectively analysing current evaluation system of applied undergraduate innovation and entrepreneurship education is necessary to establish a scientific innovation and entrepreneurship education mode, thus it could promote the development of applied undergraduate innovation and entrepreneurship education.
\end{abstract}

\section{The importance of evaluation system of the applied undergraduate innovation and entrepreneurship education}

Applied undergraduate refers to the colleges and universities that cultivate applied talents for the school-running orientation; Innovation and entrepreneurship education refers to cultivating talents with entrepreneurial basic qualities and pioneering nature. Its major goal is to train the students to possess the pioneering consciousness, spirit and ability. Evaluation system of applied undergraduate innovation and entrepreneurship education is a very important guarantee to the quality and level of innovation and entrepreneurship education. The development of innovation and entrepreneurship education depends on the scientific of evaluation system. At present, people have paid more and more attention to the innovation and entrepreneurship education. By comparison, the attention to the evaluation system is not enough, and the innovation and entrepreneurship education is focused on the influence on the economic and social research. The study and expounding for evaluation system is focus on the time cost and opportunity cost research of the education institutions, investors and educate. The utility of evaluation system of applied undergraduate innovation and entrepreneurship education can't meet the requirements of innovative entrepreneurship education development. Therefore, the research on evaluation system of innovation and entrepreneurship education has very important practical significance and theoretical significance.

\section{The main mode of evaluation system of the applied undergraduate innovation and entrepreneurship education}

Applied undergraduate innovation and entrepreneurship education is one of the most important works of college education, most evaluation systems of innovation and entrepreneurship education 
are based on the angle of college: college entrepreneurship education guiding ideology, the management of the college students' entrepreneurship education, appropriation budget, the construction of teaching staff for innovation and entrepreneurship education, college students' entrepreneurship education courses, college students entrepreneurship practice, college students' entrepreneurship competition achievement evaluation index and so on, all above were included in the evaluation system. These indexes data mainly come from colleges and universities. It's easy to make a collection for having a compare with each other. People can get clear results.

In addition, entrepreneurship rate and entrepreneurial success rate are also paid more attention in building applied undergraduate evaluation system of innovation and entrepreneurship education. Fr om the angle of measuring, entrepreneurship rate shows the practicability because of its simplexes a nd comparability. All walks of life paid more attention to the two indexes. Because of people regard college graduate's entrepreneurship situation as an important indicator of college talent training qu ality, it requires entrepreneurship rate must objectively indicate comprehensive graduate entreprene urship situation. In fact, entrepreneurship rate is only a ratio between entrepreneurship number and $t$ otal number, just a number index; it can only indicate a certain aspect of entrepreneurship situation. It does not contain the quality dimension. Therefore, it can't comprehensively evaluate the overall q uality of innovation and entrepreneurship education. For the same reason, entrepreneurship success rate is also a single response to innovation and entrepreneurship education.

Current evaluation system of applied undergraduate innovation and entrepreneurship education mainly contain some dominant indexes as shown under table 1.

Table 1 Common indexes used to evaluate innovation and entrepreneurship education

\begin{tabular}{|c|c|}
\hline & Common index \\
\hline college & 1. college entrepreneurship education guiding ideology \\
& 2. the management of the college students' entrepreneurship education \\
& 3. the construction of teaching staff for innovation and entrepreneurship education \\
4.college students' entrepreneurship education courses \\
5. college student's entrepreneurship practice \\
6. College students' entrepreneurship practice base construction \\
7.college students' entrepreneurship competition achievement \\
8.venture fund \\
society \\
1.entrepreneurship rate \\
2.entrepreneurship success rate \\
3.the social environment \\
4.jobs provided by entrepreneur \\
5.entrepreneur scale \\
6.income level of entrepreneur
\end{tabular}

\section{Some thoughts on building scientific evaluation system of innovation and entrepreneurship education}

\subsection{Multiple levels to build evaluation system}

Building scientific evaluation system of innovation and entrepreneurship education should base on multiple levels, such as government, society, college and individual. Most researchers think there is a certain hysteresis about the influence of innovation and entrepreneurship education; therefore, the comprehensive evaluation should be build. In addition, some colleges think that if we want to evaluate the level of higher education, we should evaluate higher education whether is adapt to or meet the needs of the society. Therefore, the research on evaluation system of innovation and entrepreneurship education should base on society but government. Society makes evaluation and supervision. The author thinks that building a scientific evaluation system of innovation and entrepreneurship education is not only from the aspects of government and social evaluation, should also include the college and individual development level, it is a comprehensive evaluation. For individual, the influence on entrepreneurial intention by innovation and entrepreneurship education 
is also a very important index. Through entrepreneurship education, if undergraduate have strengthened the consciousness of entrepreneurship, if set up the entrepreneurial spirit, if improved the ability of entrepreneurship. Individuate level upgrade is the most direct embodiment of innovation and entrepreneurship education development.

\subsection{Measurement from multiple dimensions}

For evaluation system of innovation and entrepreneurship education we should pay attention to two-dimension measurements, that is quantity and quality. In terms of the quantity evaluation, we should consider the number of enterprise that started by students, at the same time, we should refine indicators in detail including income situation of entrepreneurship, business scale, development prospect and so on. In terms of quality dimension, we cultivate students' comprehensive quality in education of innovation and entrepreneurship, including the pioneering consciousness, ability and entrepreneurship. We should carry on the comprehensive evaluation through quantitative and qualitative methods in innovation and entrepreneurship education evaluation system.

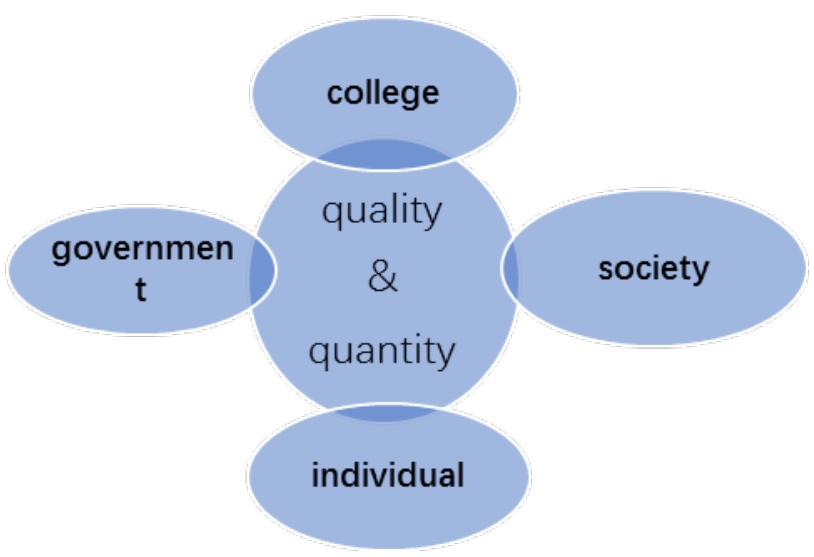

Figure 1. Multiple levels and multiple dimensions

\subsection{Drawing lessons from other successful innovation and entrepreneurship education evaluation system.}

The research on entrepreneurship education began as early as in 1919. In some countries, typical pattern of entrepreneurship education in colleges and universities includes: "Strengthen consciousness" mode of Babson college, " experience" mode of Harvard University and " systems thinking "mode of Stanford university, all have achieved good results. We can draw lessons from these successful innovation entrepreneurship education systems and carry out localization improvement, so as to build a scientific and applicable innovation entrepreneurship education evaluation system.

\section{Conclusion}

Now the evaluation system research is insufficient for innovation and entrepreneurship education. To building scientific evaluation system of innovation and entrepreneurship education it should be more comprehensive and in-depth. Overall analysis of the current evaluation system of innovation and entrepreneurship education could accelerate the development of higher education. Continuously review and analyze the scientific and applicability of evaluation system is still necessary, the author will keep researching the subject in the future.

\section{References}

[1]. Tao Hong. The building of evaluation system of applied undergraduate innovation and entrepreneurship education [J]. Journal of Qiqihar university (Philosophy and social sciences),2015, (11):145-147. 
[2]. Zhan Ren, Zhi Liu, Haibin Liu, Yayuan Li. The status, problems and trends about innovation and entrepreneurship education evaluation [J]. Ideological and theoretical education, 2016, (08):89$94+103$.

[3]. Deqin Jiang. The building of evaluation system of college innovation and entrepreneurship education [J]. Innovation and entrepreneurship education,2015, (06):1-4.

[4]. Ying $\mathrm{Xu}$, Hua Bai. The research of college evaluation system of college innovation and entrepreneurship education [J]. Innovation and entrepreneurship education, 2014, (02):29-33. 